\title{
Rhizolith balls from the Lower Cretaceous of Patagonia: Just roots or the oldest evidence of insect agriculture?
}

\author{
Jorge F. Genise a,*, Ana María Alonso-Zarza ${ }^{\text {b }}$, J. Marcelo Krause a , M. Victoria Sánchez c, Laura Sarzetti a , \\ Juan L. Farina ${ }^{\mathrm{d}}$, Mirta G. González ${ }^{\mathrm{c}}$, Marcela Cosarinsky ${ }^{\mathrm{e}}$, Eduardo S. Bellosi ${ }^{\mathrm{c}}$ \\ a CONICET, Museo Paleontológico Egidio Feruglio, Av. Fontana 140, 9100 Trelew, Chubut, Argentina \\ b Departamento de Petrología y Geoquímica, Facultad de Ciencias Geológicas, IGE-CSIC, Universidad Complutense de Madrid, 28040 Madrid, Spain \\ CONICET, Museo Argentino de Ciencias Naturales, División Icnología, Av. Ángel Gallardo 470, 1405 Buenos Aires, Argentina \\ d Area Entomología. Museo Municipal de Ciencias Naturales Lorenzo Scaglia, Plaza España, 7600 Mar del Plata, Buenos Aires, Argentina \\ e Museo Argentino de Ciencias Naturales, División Icnología, Av. Ángel Gallardo 470, 1405 Buenos Aires, Argentina
}

\section{A R T I C L E I N F O}

\section{Article history:}

Received 1 April 2009

Received in revised form 16 November 2009

Accepted 21 January 2010

Available online 28 January 2010

\section{Keywords:}

Rhizolith balls

Cretaceous

Patagonia

Insect trace fossils

Insect agriculture

\begin{abstract}
A B S T R A C T
A new type of trace fossil from the Lower Cretaceous of Patagonia that may record the oldest evidence of insect agriculture is represented by biconvex, sub-spherical, carbonate balls composed of a dense mass of rhizoliths. The best preserved balls show an external wall, a tunnel entrance, and vertical, large rhizoliths crossing from top to base, from which a mass of smaller rhizoliths arise. In some cases there is a pelletal surface texture in internal layers of the wall. Some specimens show meniscate tubes attributed to organisms different than the constructors of the chambers, probably attracted by the original organic matter. Micromorphology, analyzed by thin sections and SEM, shows strong evidence of high fungal activity associated to the original roots.

Four different hypotheses are analyzed to explain the origin of the balls. The less probable ones are either that the balls were produced only by a self induced and localised overgrowth of secondary and tertiary rootlets from a group of neighbouring primary roots, or that they were crayfishes' feeding chambers. Rhizolith arrangement, as well as other characters, essentially rule out both hypotheses. The hypotheses involving social insects, termites and ants, are more risky, considering the lack of support from the body fossil record, the biogeography of these extant insects, and particularly the lack of definitive evidence of discrete fungus or bacterial gardens in the balls. However, the trace fossils described herein partially resemble the nests and behaviour of the African termite Sphaerothermes sphaerothorax, particularly because of the presence of roots inside a thick lined chamber excavated around them to cultivate bacterial combs. The ant origin of these balls is at least a hypothesis to explore considering the size, shape, wall, entrance tunnel, presence of traces of associated organisms, and particularly roots. The roots and wall relate these balls to hypothesised scenarios for the origin of fungus agriculture in ants. One hypothesis suggests that primitive Attini developed fungus agriculture from the habit of feeding on fungi associated with roots (mycorrhizae) and still other proposes that adventitious fungi on nest walls were responsible for the arise of fungiculture. The balls would supply physical evidence that by the lower Cretaceous some social insects excavated chambers around uncut roots, which in turn provided optimal conditions for fungi development. These rhizolith balls possibly constitute the oldest physical evidence for the origin of fungiculture in social insects, and represent a critical contribution of ichnology to this hot topic intensively discussed on the basis of a scattered body fossil record and molecular phylogeny.
\end{abstract}

\section{Introduction}

The origin of social insect agriculture, particularly in ants of the tribe Attini, has been a hot topic over the last few years since the incorporation of molecular techniques for studying phylogeny and coevolution among attines, fungus cultivars, and actinomycete bacteria. Different hypotheses have been proposed based on phylogeny,

\footnotetext{
* Corresponding author.

E-mail address: jgenise@macn.gov.ar (J.F. Genise).
}

body fossil record, historical biogeography, and other topics (Chapela et al., 1994; Mayhé-Nunes and Jaffé, 1998; Mueller et al., 1998, 2001, 2005; Currie et al., 1999, 2003; Munkacsi et al., 2004; Villesen et al., 2004; Sánchez-Peña, 2005, Schultz, 2007; Mueller and Rabeling, 2008; Schultz and Brady, 2008). However, data provided by trace fossils, the only physical evidence of behavioural evolution, was lacking until now. In contrast, mutualistic relationships between termites and fungi, and particularly fungiculture of the single fungus Termitomyces by the Macrotermitinae, seems to follow a simpler, and therefore easier to understand model (Rouland-Lefévre, 2000). The outstanding African taxon, Sphaerotermes sphaerothorax, whose 
nests resemble in part the trace fossils described herein, was considered at once a fungus growing termite and was included in the Macrotermitinae, the subfamily of the other fungus growing termites (Grassé and Noirot, 1948). More recent studies have demonstrated that it is a xylophagous termite cultivating bacterial combs associated with roots (Eschenbrenner, 1986; Garnier-Sillam et al., 1989). It was also placed in its own subfamily: Sphaerotermitinae (Engel and Krishna, 2004).

Conversely, the study of rhizoliths has been based mostly on traditional papers describing the most common morphologies (Klappa, 1980), and only recently more complex forms have been described and interpreted in detail (Kraus and Hasiotis, 2006; Alonso-Zarza et al., 2008; Cramer and Hawkins, 2009). The material described herein, besides its importance as possible evidence of insect agriculture, presents a new type of rhizolith morphology unknown until now.

The objective of this contribution is to describe and interpret this new type of trace fossil from the Lower Cretaceous of Patagonia that may represent the oldest evidence of insect agriculture, and to analyse its contribution to the current ideas about the origin of fungiculture in social insects.

\section{Geologic setting}

The study area is located in the Estancia El Dinosaurio ( $\mathrm{S} 43^{\circ} 23^{\prime}$ 7.7" W $68^{\circ} 21^{\prime} 26.4^{\prime \prime}$ ), about $250 \mathrm{~km}$ westward from Trelew city, in the province of Chubut, Argentina (Fig. 1). Extensive outcrops belonging to the Chubut Group characterise this area, showing successions from hundreds to thousands of meters thick (Lesta, 1968; Chebli et al., 1976; Codignotto et al., 1978; Proserpio, 1987). The Cretaceous rocks of the Chubut Group overlay a markedly irregular palaeo-relief that is constituted by Jurassic volcanic rocks (Musacchio and Chebli, 1975). Structure in the studied area, east of Arroyo Perdido, is characterized by NW oriented normal faults. Stratification shows a gentle dipping to the SE. Two different stratigraphic schemes exist for the study area. According to one of the schemes, the Chubut Group is composed of Gorro Frigio, Cañadón de las Víboras and Puesto Manuel Arce Formations (Chebli et al., 1976). According to the other one, the Chubut Group is composed of the Los Adobes and Cerro Barcino Formations (Codignotto et al., 1978) (Fig. 1). Herein the latter is followed; although differences between both schemes deserve a future revision of the stratigraphic relationships. Trace fossils bearing rocks correspond to the Bayo Overo Member, in the upper section of the Cerro Barcino Formation. This member is constituted by greenish yellow sandstones and tuffs, conglomerates, and scarce mudstone intercalations. Cerro Barcino Formation (Cerro Barcino Member Chebli et al., 1976) is assigned to the Aptian-Albian. Evidence from charophyte associations (Musacchio, 1972) and ostracods and charophytes in outcrops located to the west of the study area suggests Lower Cretaceous, particularly Aptian age (Musacchio and Chebli, 1975). According to Proserpio (1987) the Bayo Overo Member could be up to Cenomanian in age.

At Estancia El Dinosaurio, the section is a $16 \mathrm{~m}$ thick, finningupward succession composed of coarse, to very fine, siliciclastic sandstones in the lower section, and subordinate tuffs and mudstones in the upper one (Figs. 2 and 3). The base of the section is not exposed. The lower section includes a coarse sandstone body, $3 \mathrm{~m}$ thick, with an erosive base covered by volcanic and intraformational clasts. Sandstone presents low angle trough bedding. Current ripples occur at the top of each set. These deposits are followed by fine to very fine sandstones showing parallel or massive lamination with rhizoliths and invertebrate burrows. An indurated carbonate horizon, $0.3 \mathrm{~m}$ thick, with cylindrical and branching rhizoliths is preserved in this slightly pedogenised facies. The upper section is composed of thinner and tabular beds of fine to very fine tuffs and mudstones with calcareous concretions and parallel lamination, partly obscured by bioturbation and pedogenesis. In the middle part of this section a complete profile of a palaeosol occurs, which contains the studied trace fossil, called herein rhizolith balls.

The described succession originated in a fluvial system. The lowermost sand body corresponds to a filled fluvial channel where 3D megaripples mobilised sand grains. The overlaying finer facies represent floodplain deposits. The lower siliciclastic fine sediments were accumulated by sheet flood episodes and overbank flows from the channel, whereas the upper fine pyroclastics were probably supplied from volcanic ash falls. The presence of paleosols and the abundance of trace fossils suggest a low and probably discontinue sedimentation on plains. The channel fill and floodplain deposits are recurrent in other outcrops of the Bayo Overo Member, in the same study area and at similar stratigraphic levels. Laterally equivalent, few kilometres away, channel facies contain abundant and wellpreserved dinosaur bones (e.g. Chubutisaurus insignis) (Carballido et al., 2008). In this case, epsilon trough-cross bedding suggests high sinuosity channels.

The tuffaceos palaeosol bearing the rhizolith balls is formed by three horizons (Fig. 3B). Boundaries among them are transitional. The upper horizon is a $0.55 \mathrm{~m}$ thick, light pinkish white (5YR9/1) massive fine tuff, which contains a few centimetres in diameter, subspherical to oblate calcareous concretions and a network of small size ( $c a .0 .5 \mathrm{~cm}$ diameter) burrows. Large, rectilinear, horizontal rhizoliths, up to $10 \mathrm{~cm}$ in diameter and up to $200 \mathrm{~cm}$ long are also present (Fig. 2). The middle horizon is also a fine tuff with a coarse granular structure, $45 \mathrm{~cm}$ thick, pinkish white (5YR9/1) to white (5YR8/1) in colour, showing diffuse parallel lamination. In some sectors there is an intense bioturbation ( $\mathrm{ca} .1 \mathrm{~cm}$ in diameter) consisting of a boxwork of horizontal burrows. Rhizoliths balls occur in this horizon and in the contact between the middle and the lower ones (Fig. 3B and E). The lower horizon is a $38 \mathrm{~cm}$ thick, light grey (5YR7/1) very fine tuff also showing coarse structure and poorly defined parallel lamination.

Thin sections of the palaeosol show a pedal microestructure with very low porosity $(<1 \%)$. The grain size of the coarse fraction (almost $10 \%$ ) ranges from silt to fine sand, and is mostly composed of tabular plagioclase and feldspar, with subordinate quartz. The former presents zonation and both (feldspar and plagioclase) show macles and alteration in some cases. The fine fraction shows light yellow and brown clays with abundant opaque material. The groundmass is double-spaced porphyric. It shows moderate to weak development and an undifferentiated punctuated to weakly cross striated b-fabric. The only recognisable pedofeatures are Fe-Mn nodules. The weak alteration degree of the tuffaceous parent material, the moderate horizonation, the scarce pedofeatures, and the preservation of the original bedding are characteristics of a moderate to weakly developed palaeosol. Consequently, it corresponds to an Andisol or less probably to an andic Entisol.

\section{Description of trace fossils}

The International Code of Zoological Nomenclature identify the trace fossils as the "fossilized work of organisms" including in the latter not only animals, but also protistans, plants, and fungi. However, there have been no attempts among ichnologists to deal ichnotaxonomically with plant traces, mostly root traces (Mikuláš, 1999, Genise, 2006). Thus, since these structures are in the simplest approach root traces in which the participation of animals, based on the presence of a chamber, is more interpretative, it is preferred for this contribution to avoid their ichnotaxonomical treatment until new evidence or another approach indicate its necessity. Accordingly, they will be referred to as "rhizolith balls" or just "balls" along the text. The material is housed at the ichnological collection of the Museo Paleontológico Egidio Feruglio (MPEF-IC) at Trelew, Chubut, Argentina. 


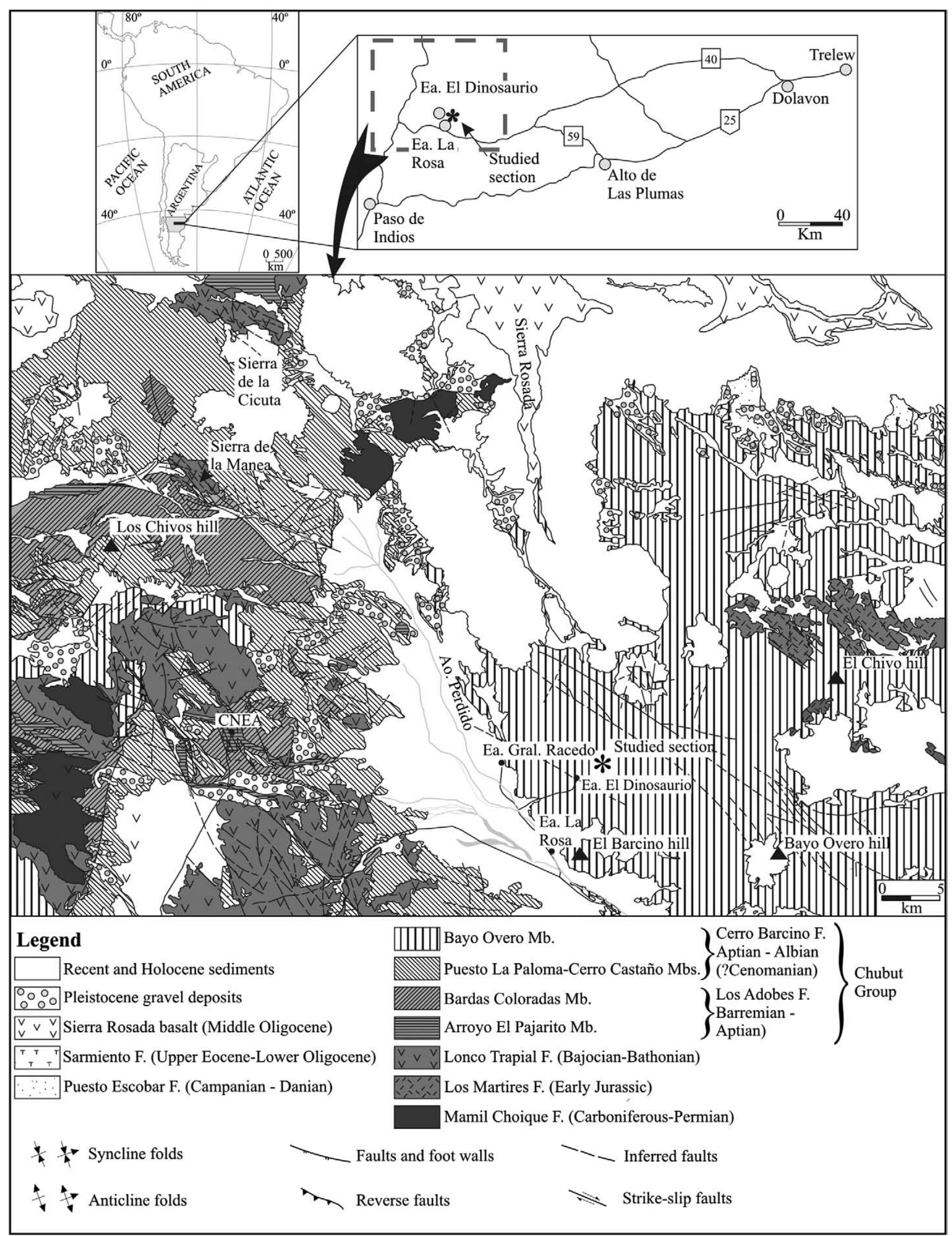

Fig. 1. Location map of the studied locality. The geologic map modified from Proserpio (1987). 


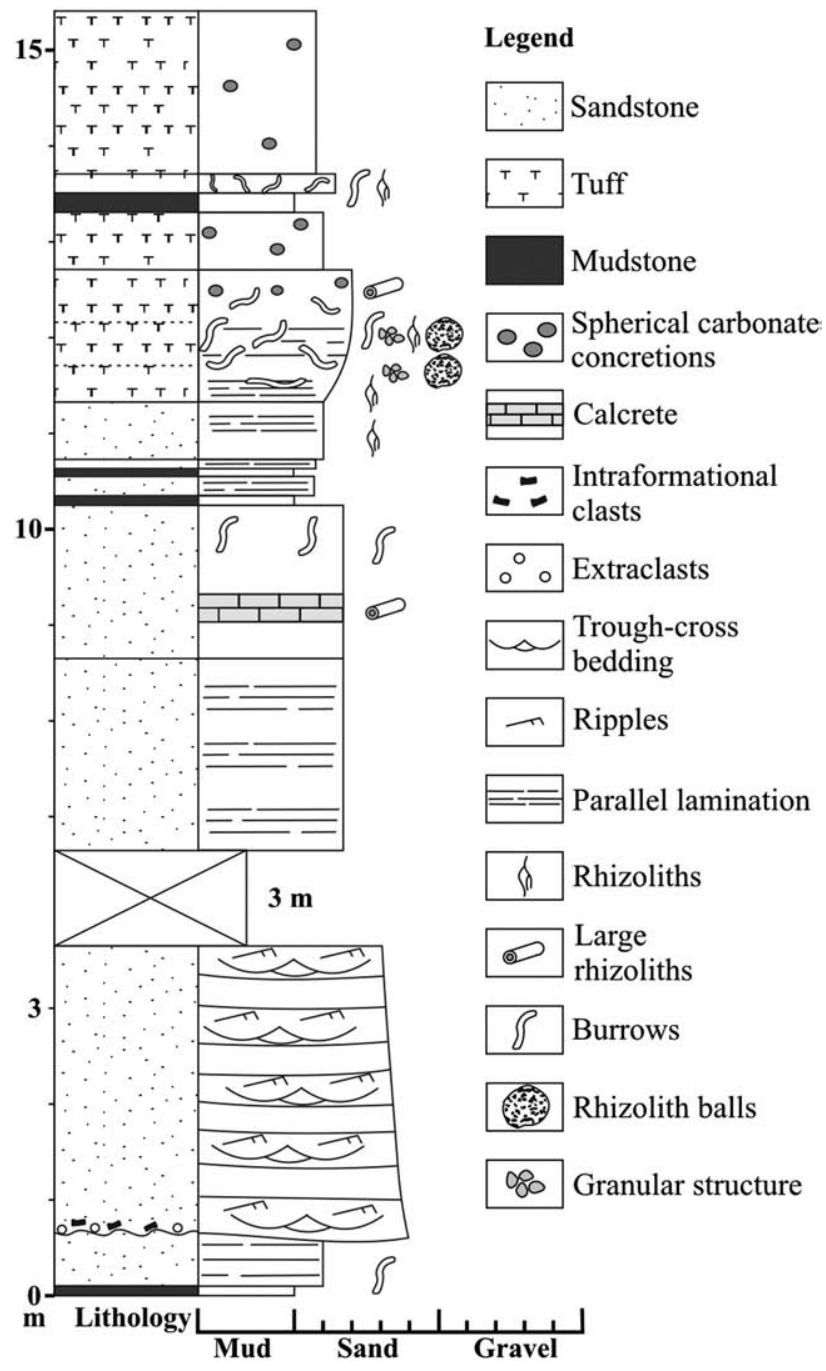

Fig. 2. Sedimentological log of the studied section.

\subsection{Macromorphology}

Description is based on 371 collected specimens (MPEF-IC 543599 and 701-719) from which 123 were complete ones used to identify the shape and to take measurements. Three basic shapes were recognised: Type (1) symmetrical biconvex ( $N: 46,38 \%$ ), in which the largest horizontal cross section of the specimen is located at the equator (Fig. 4A), Type (2) asymmetrical biconvex ( $N$ : 54, 44\%), in which the largest horizontal cross section of the specimen is located near its base resembling a plane-convex shape (Fig. 4B), and Type 3) Asymmetrical biconvex with a basal ring ( $N$ : $23,18 \%)$, which is characterized by the presence of a flat annular surface surrounding the base of the specimen (Fig. 4C). The latter type may be a preservational variant of the former ones, more probably of type 2 , in which a concave-convex piece of the base is lacking. Morphological variants within these types include flattened versus more rounded specimens. Specimens range from 10,8 , and $5 \mathrm{~cm}$ to 43,28 , and $20 \mathrm{~cm}$ in length, width and height respectively (mean: $19 \times 16 \times 12 \mathrm{~cm}, \mathrm{~N}$ : 123). Most specimens (65\%) are $15-20 \mathrm{~cm}$ long, $12-17 \mathrm{~cm}$ wide, and in height from 9 to $15 \mathrm{~cm}$ high, with a secondary mode of $14 \%$ of the specimens ranging in length from 22 to $23 \mathrm{~cm}$ long, 19-20 cm wide, and $17-18 \mathrm{~cm}$ high. A mean specimen (about one third of the cases), considering the modes of each one of the values, would be $17 \mathrm{~cm}$ long, $14 \mathrm{~cm}$ wide and $12 \mathrm{~cm}$ high, slightly shorter and narrower than when considering also the extreme values. The mode of the height matches the mean value for the same parameter.
Apart from the collected specimens, most of which were detached from the palaeosol and spread on the outcrops talus (Fig. 3D), a few specimens were still encased in the palaeosol. Three specimens could be observed in the best exposed vertical section of the outcrop (Fig. 3B). Other specimens occurring in the same level were exposed on a horizontal bedding plane laterally at the top of the outcrop (Fig. 3C). Specimens observed in vertical section show a smooth texture externally, and in one case they show remains of a tunnel, $2 \mathrm{~cm}$ in diameter, entering the structure near the base (Fig. 3F). Other collected specimens show remains of this tunnel, ranging in diameter from 0.8 to $4 \mathrm{~cm}$ (mean: $2.2 \mathrm{~cm}, N: 18$ ). At the same level of the balls occurs a boxwork of mostly horizontal burrows of about $1 \mathrm{~cm}$ in diameter, which is overlaid by another level bearing smaller, more densely grouped, tunnels, $0.5 \mathrm{~cm}$ in diameter (Fig. 3E). The balls are brown in colour, in contrast to the whitish rock matrix. Vertical, small, and whitish rhizoliths could be observed also in the palaeosol around the balls (Fig. 3G).

The smooth surface texture of the specimens in situ is given by the presence of a wall (Fig. 3E). In some of the detached and broken specimens, in which it could be measured, this wall ranges in thickness from 0.15 to $1.5 \mathrm{~cm}$ (mean: $0.62 \mathrm{~cm}, N$ : 14) (Fig. 4D-L). The outer layer of the wall lacks any recognisable surface texture apart from some small ridges and pits probably produced by weathering. Impressed on it there is a net of whitish rhizoliths, which do not penetrate the wall, but curve and bend adopting the shape of the ball (Fig. 4F). In one case the outer wall, in contact with a vertical rhizolith, seems to gently curve around it, or it may be a product of differential weathering (MPEF-IC 573) (Fig. 4G and H). In some specimens the walls are weathered in such a way that other details can be observed, particularly when the outer layer is missing and the internal structure of the wall is exposed. Specimen MPEF-IC 701 shows on top an internal layer of the wall with piercing minute holes (Fig. 4I), in a few cases surrounded by a ring interpreted as rhizolith cross sections. The same internal layer shows a pelletal texture that at some places composes a ridged pattern (Fig. $4 \mathrm{~J}$ and $\mathrm{K}$ ). Other specimens also show these holes or pelletal texture on the internal exposed layers of the wall (Fig. 5R). Weathered walls show a net of rhizoliths included in them, which in some cases produces the misleading appearance of double walls (Fig. 4L).

Weathered balls are internally composed of a mass of rhizoliths. (Figs. 4A and 5A-B). This mass arises from main vertical rhizoliths ca. $9 \mathrm{~mm}$ in diameter, which can be observed (1) crossing the weathered cores of specimens from top to bottom (Fig. 5C-E), (2) densely packed on the roof of some balls lacking the wall (Fig. 5F-G), or (3) projecting outside the top of the balls (Fig. 5H-I). From these first order vertical rhizoliths, other second-order rhizoliths $c a .4 \mathrm{~mm}$ in diameter arise, which in some cases show a radiating pattern in cross section, and from these, still third order ones (ca. $2 \mathrm{~mm}$ ) arise (Fig. 5J-N).These secondary and tertiary rizholiths are oriented in all directions, crossing themselves frequently, resulting in an intricated boxwork. Some rhizoliths show small holes in their wall as if the original root would have been pierced by some organism (Fig. 50). Meniscate burrows are very common among the mass of rhizoliths. They are mostly horizontally oriented, and $0.2-1 \mathrm{~cm}$ in diameter (mean: $0.5 \mathrm{~cm} ; \mathrm{N}$ : 50) (Fig. 5P-S).

A single specimen significantly smaller than the rest is included tentatively herein as a young variant, since it shows some characters of the larger specimens. It was exposed in a fallen block, broken and showing its internal structure. The core is $25 \mathrm{~mm}$ in diameter, structureless, and surrounded by an $8 \mathrm{~mm}$ layer that in some sectors shows crossing rhizoliths (MPEF-IC 587) (Fig. 3H).

\subsection{Micromorphology}

Thin sections of the balls show a complex microstructure consisting of an irregular distribution of darker and whitish patches. 

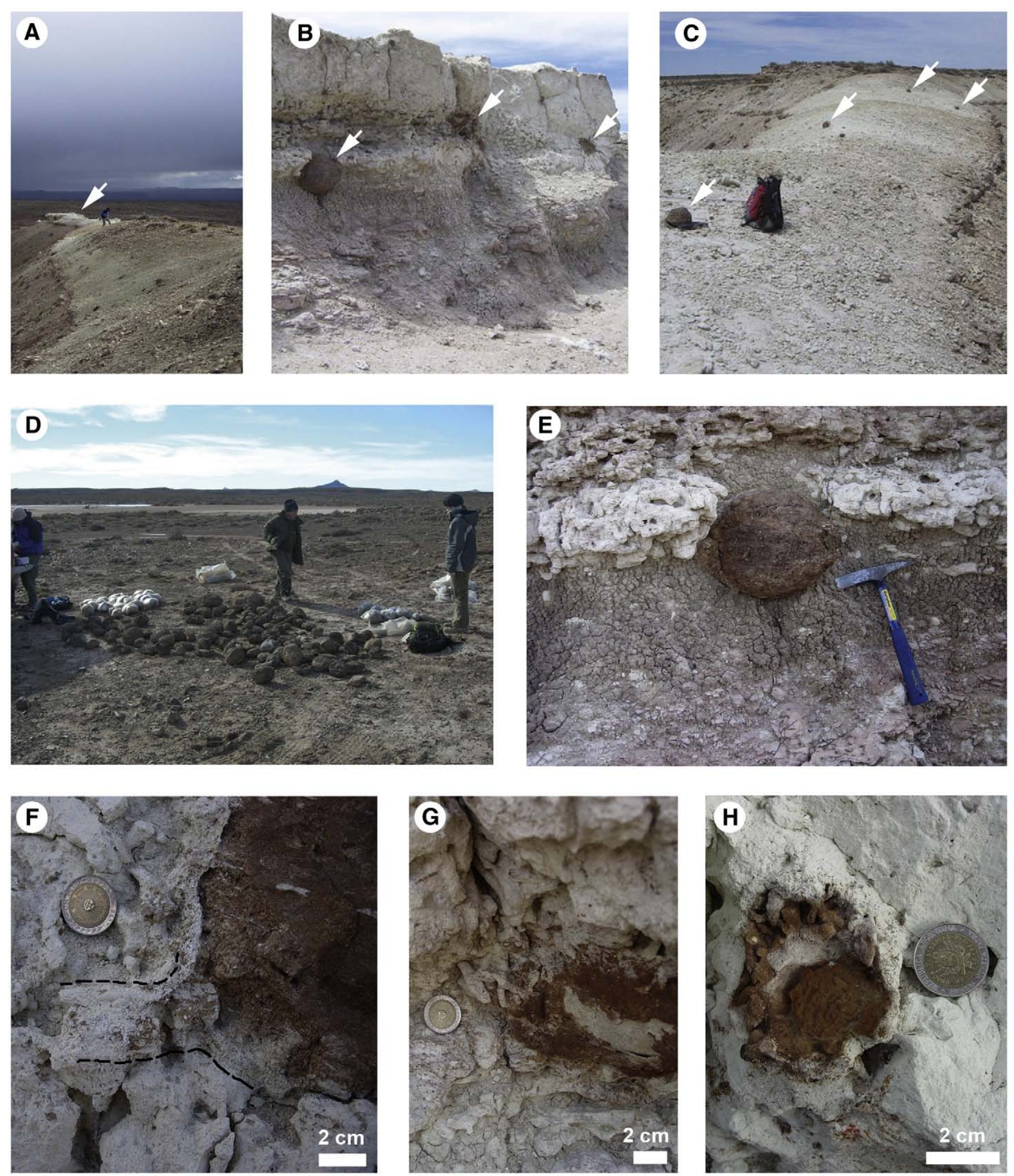

Fig. 3. (A) General view of the outcrop. The arrow shows the section bearing the balls. (B) Studied section with three rhizolith balls (arrows) in situ. (C) Balls (arrows) exposed on a horizontal bedding plane laterally at the top of the outcrop. (D) Some of the detached balls at the base of the outcrop being collected and packed. (E) One of the balls in situ showing associated burrows. (F) Entrance tunnel marked with dash lines. (G) White vertical rhizoliths beside a ball in situ. (H) Potential small specimen in situ.

Fig. 4. Ball macromorphology. (A) General aspect of a symmetrical biconvex ball. Note that the widest section (arrows) is at the equator. (B) Asymmetrical biconvex shape, the widest section (arrows) is closer to the base producing a more plane-convex outline. (C) Asymmetrical biconvex shape showing a flat ring at the base (arrows), probably by detachment of a basal piece of the specimen. (D) and (E) Cross sections of walls. (F) External surface of a wall showing the net of white rhizoliths. (G) and (H) Piece of wall showing an attached white vertical rhizolith. (I) Top portion of a ball showing an inner layer of the wall pierced by small holes interpreted as root traces. (J) Pelletal texture composed of ridges on an inner layer of the weathered wall. (K) Detail of pelletal texture. (L) Piece of weathered wall resembling a double or triple layered structure. 


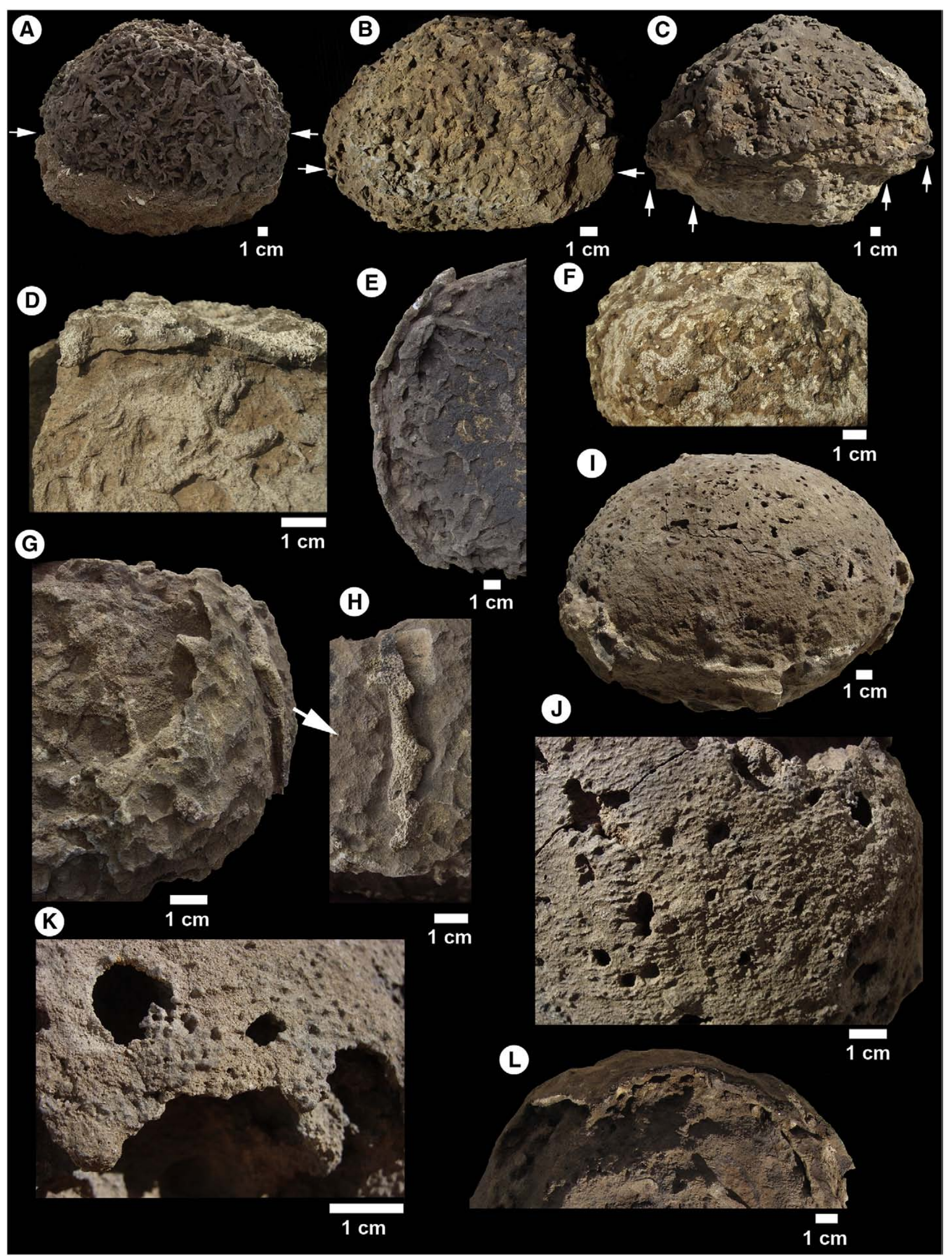


There is also a diffuse change from the outer to the inner parts of the balls. The most external parts consist of an irregular micrite groundmass with abundant quartz, plagioclase, and volcaniclastic grains (mean size of $0.25 \mathrm{~mm}$ ). Analcime has been identified by XRD. Patches of calcite pseudospar are irregularly distributed (Fig. 6A). The calcite crystals, $4 \mathrm{~mm}$ across, are very anhedral. Both micrite and pseudospar corrode and etch the silicate grains. Denser micrite aggregates with rounded morphologies, around $2.5 \mathrm{~mm}$ across, are occasionally recognised (Fig. 6B). These aggregates also include silicate grains. Root structures are only locally recognised as long (cm) and narrow (up to $2 \mathrm{~mm}$ ) irregular voids lined by micrite and containing thin micritic lines joining the two walls (Fig. 6C). Micritic peloids are occasionally found (Fig. 6D). Irregular micritic lines (filaments) are distributed around the silicate grains and all along the external part - very commonly forming an alveolar fabric (Fig. 6E-F). Near the filaments, rounded calcite crystals of about $0.2 \mathrm{~mm}$ occur, which also show micritic coatings. Under SEM, abundant organic films and filaments are intergrown with the groundmass (Fig. 7A-C). The organic films and filaments are in most cases quite homogeneous, but in one case a more complex structure consisting of a network of voids has been observed (Fig. 7C). Some of the filaments show the presence of micrite-size calcite crystals on them (Fig. 7A). In some cases the organic films are more disintegrated and small calcite fibre crystals can be recognised (Fig. 7D). Search for phytoliths along different samples had negative results.

The most internal parts (a few centimetres from the cortex) consist mostly of a dense mosaic of coarse $(0.4 \mathrm{~mm})$ anhedral pseudospar, with relics of micrite and filaments. It also contains silicate grains. In appearance these internal parts are the whitest. It is likely that the whiter areas of the balls correspond to pseudospar zones.

\section{Discussion}

\subsection{Structures produced just by roots and fungi?}

In continental deposits, the precipitation of carbonate in roots mediated by microorganism activity, particularly fungi, and/or transpiration-driven mass-flow of cations to roots are processes that result in rhizoliths (Klappa, 1980; Cramer and Hawkins, 2009). Micromorphological analysis of the material presented herein demonstrates the occurrence of micrite filaments all along the groundmass, forming alveolar-septal structures, coating the grains, and also shows the presence of partially calcified filaments. All these characters result from the biomineralization of fungal hyphae (Wright, 1986) and demonstrate high fungal activity around the original root masses. The decomposition of some of the organic structures to form incipient calcite needle crystals is another evidence of fungal activity (Verrecchia and Verrecchia, 1994; Loisy et al., 1999). The rounded calcite crystals that occur near the filament, very probably represent different fungal structures. Alonso-Zarza et al. (1998) described smaller spheroidal structures interpreted as fungal peritecium in Quaternary calcretes from SE Spain.

In our case study other root traces in the same paleosol horizon of the rhizolith balls are not particularly cemented by carbonate or highly branched. The micromorphological analysis of this horizon does not reveal any evidence of carbonate either. In consequence, the balls reflect the existence of a localized high concentration of carbonate, probably responding to high fungal activity associated to the overgrowth of roots and rootlets, as in the case of cluster roots (Cramer and Hawkins, 2009).
Is it possible for roots and fungi to produce these balls by themselves? Mycorrhizes form diffuse networks that even connect roots of different plants (Giovannetti et al., 2004; de la Providencia et al., 2005), but do not compose closed rounded structures. The same is true for high root concentrations and ectomycorrhizal networks of mycoheterotroph plants (Bidartondo et al., 2000). The so-called root clusters, cluster roots or proteoid roots, recognised for different families of plants and mainly present in Proteaceae, are composed of dense clusters of rootlets along a root axis (Skene, 1998; Newmann and Martinoia, 2002; Lamont, 2003; Shane and Lambers, 2005; Cramer and Hawkins, 2009). Even when these clusters may resemble at first glance the rhizolith balls described herein, there are several significant differences. Cluster roots are mostly bottlebrush-like clusters of fine, similar diameter, regularly arranged rootlets arising from a main single root (Skene, 1998; Lamont, 2003), an arrangement that is completely different from that recorded in the fossil structures. The cemented root clusters show a distinct concentric structure (Cramer and Hawkins, 2009) that is absent in the rhizolith balls. Not only the arrangement of rhizoliths but also the presence of an external wall covering the whole structure and the entrance tunnel, discard the production of balls exclusively by this type of mycorrhizes.

Tuberculate ectomycorrhizas are clusters of mycorrhizes enclosed by a rind of fungal tissue (Dell et al., 1990; Peterson et al., 2004), which may resemble the rhizolith balls superficially. However, they are small in size, grouped in clusters, and associated with a single main root from which a net of similar sized ectomycorrhizas and rhizomorphs arise. The roots which compose the rhizolith balls arise from many vertical roots that cross the ball vertically.

Accordingly, it is then necessary to consider the participation of other organisms in the production of the balls, which will be analyzed in the next sections.

\subsection{Crayfish feeding chambers?}

Empty spaces, increased availability of $\mathrm{O}_{2}$, and high humidity are factors that favour the growth of mats of adventitious roots and even a felt of fungal hyphae in walls of animal burrows and chambers in soils (Martin and Bennett, 1977; Richardson, 1983). In consequence, the overgrowth of the rhizolith balls' roots could be explained in the most likely scenario by the presence of an empty chamber constructed by an organism. The balls' regular shape and size, their external wall and other minor characters described herein attest to this fact.

Micromorphological analysis does not support the presence of an empty chamber as clearly as macromorphological characters do because some of the primary microfeatures are lost by diagenesis, and particularly recrystallization. The micromorphology of the balls is the result of both the initial precipitation of micrite and a later recrystallization to pseudospar. Micrite could be formed either by replacement of soil/sediments or by precipitation within a cavity or both. Some micrite seems to corrode the silicate grains indicating its growth after the grains were deposited. However, if the cavity contained soft sediment or organic material, micrite could have partially precipitated in the space left by the decomposition of these materials within the cavity. Recrystallisation was more effective in the inner part of the ball due to the lack of infiltrated material from the overlying soil or sediments there. However, it was a very irregular process with no clear boundaries. Recrystallisation occurred when the cavity was completely filled with water under phreatic conditions,

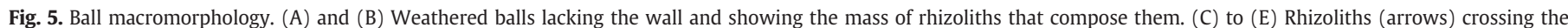

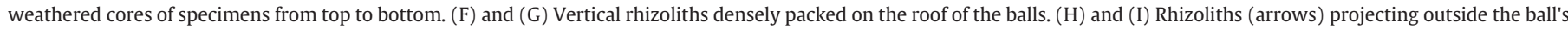

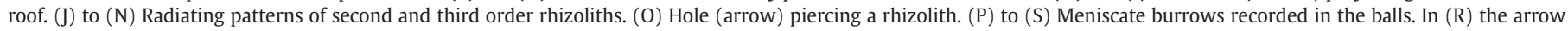
shows a pelletal texture. 


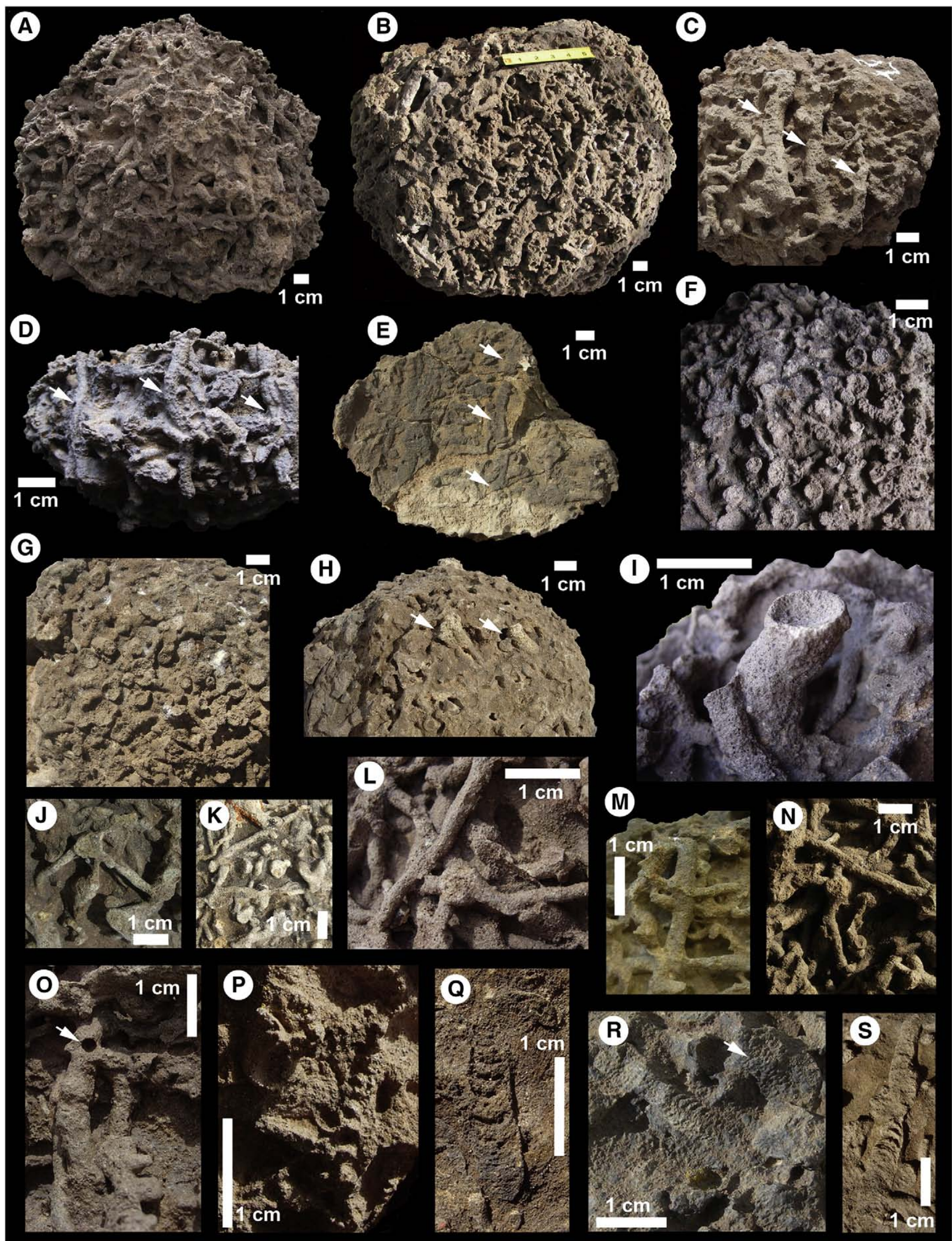



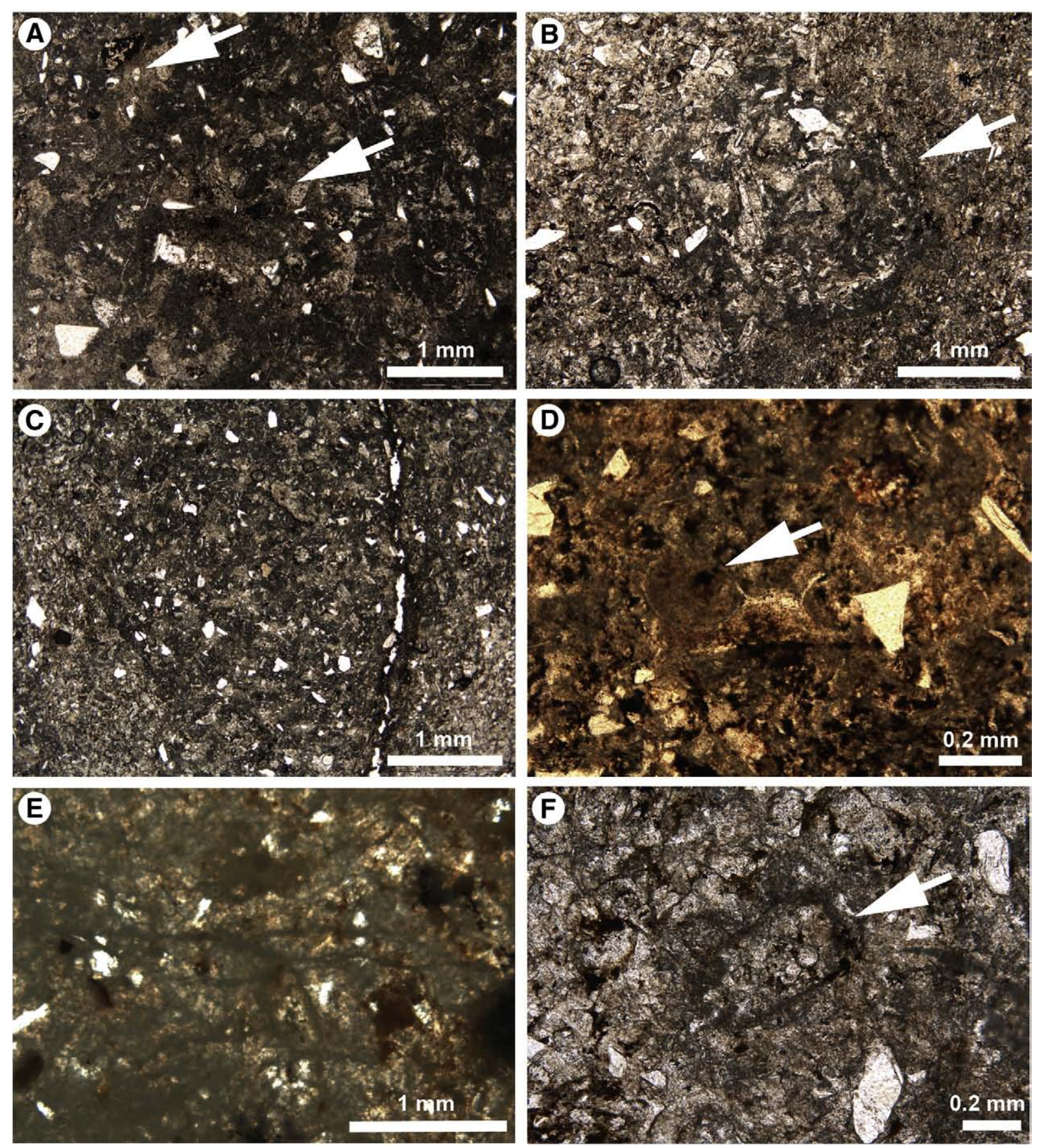

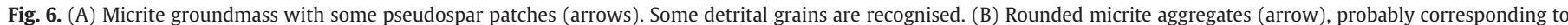

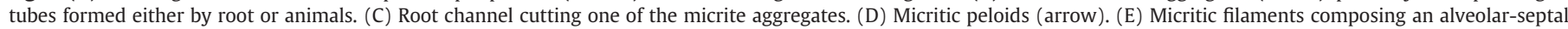
fabric. (F) Micritic filaments (arrow) coating previously detritic grains and distributed sparsely along the sample.

because there are no signs of vadose diagenesis, such as gravitational cements. The entrance of groundwater within the cavities was favoured by the porosity within the cavity of the previously formed micritic ball.

Which could be the potential producer of empty chambers favouring the growth of roots in those lower Cretaceous soils? Richardson (1983), Growns and Richardson (1988), and Richardson and Wong (1995) described crayfish chambers lined with a mat of root hairs, rootlets, and a dense felt of fungal hyphae, which are used as food by these crustaceans. The age, the geographical location of the balls, the wall lining, and particularly the presence of root mats and fungus are characters that would support a crayfish origin for these balls. Even when there is only a single record of crayfish trace fossils in the Cerro Barcino Formation (Genise et al., unpub.), crayfish burrows have been considered as the dominant trace fossils of other Patagonian Lower Cretaceous palaeosols in the Baqueró Group (Bedatou et al., 2008; Genise et al., 2008). Accordingly, considering age and location, crayfishes would be potential producers of chambers in the Lower Cretaceous Cerro Barcino Group. The tunnel boxwork that occurs at the same level as the balls could be attributed to crayfishes, although the diameter of the tunnels is much smaller than the ball's diameter. The tunnel present in some balls seems to be comparatively small in relation to the large size of the chambers. Therefore, it cannot be attributed with certainty to crayfishes, in which the chambers are enlargements of the 

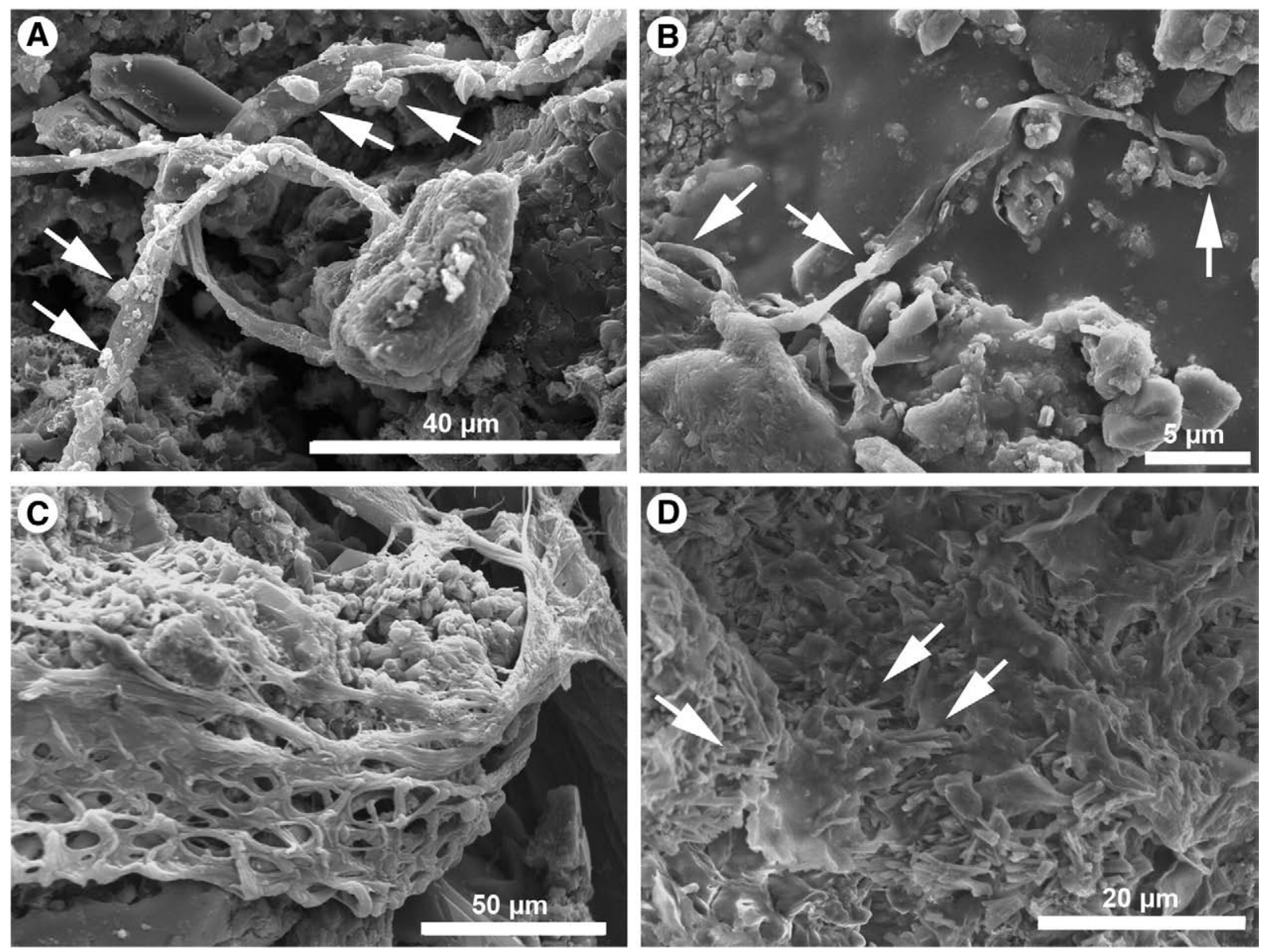

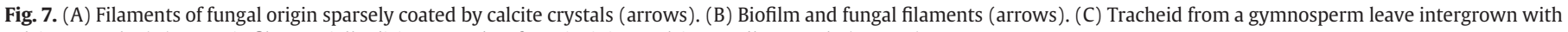
calcite crystals. (D) Organic film partially disintegrated to form incipient calcite needle crystals (arrows).

tunnels. Also, the balls are not located at the top of the system near the soil surface as is the case with the feeding chambers of some Tasmanian crayfishes (Growns and Richardson, 1988). The external wall of the balls is not recorded in crayfish feeding chambers, although there is a constructed lining in Patagonian crayfish fossil burrows (Bedatou et al., 2008).

Growns and Richardson (1988) and Richardson and Wong (1995) respectively, described the feeding chambers that the Tasmanian crayfishes Parastacoides tasmanicus tasmanicus and Parastacoides sp. excavated beneath plants to produce these root mats to feed on. They are irregular in shape and devoid of roots crossing the cavity (Growns and Richardson, 1988, Fig. 1). Rudolph (1997) also found that roots are cut at the roof of chambers by the South American crayfish Parastacus nicoleti. A mat of adventitious roots line the burrows of this species, which are devoid of crossing roots (Bedatou et al, unpub.) (Fig. 8A). Other crayfishes' tunnels are reported either to avoid (Hobbs, 1981; Horwitz et al., 1985) or to cut roots, which in some cases are used as food (Lake and Newcombe, 1975; Suter and Richardson, 1977; Horwitz and Knott, 1983). In parallel with observations on extant crayfish feeding chambers, mats of adventitious, millimetre roots were recorded in the walls of fossil crayfish burrows (Bedatou et al., 2008, fig. 5E), insect burrows (Yelinek and Chin, 2007) and more commonly in vertebrate burrows (Barbour, 1897, fig. 33; Martin and Bennett, 1977; Smith, 1987, fig. 8; Hasiotis et al, 2004, fig. 4F; Gobetz, 2006, fig. 8). Martin and Bennett (1977), when describing the fossil mammal burrow Daimonelix, explained that the burrows were kept free of roots by the occupant activity, but when abandoned, the roots invaded the cavity, which were also recorded in other vertebrate fossil burrows (Dubiel et al., 1987; Gobetz, 2006; Melchor and Genise, unpub) (Fig. 8B). Martin and Bennett (1977) noted that when new roots invaded the burrow, they followed its long axis, with few ones cutting across from one wall to the other.

In the rhizolith balls studied herein the arrangement of roots is completely different. The root mat is composed of second and third order rootlets, arisen from vertical, first order roots crossing the structure from top to bottom. These original first order roots were apparently never cut. The cavity was excavated and probably lined including the first order roots, which then, favoured by oxygen, open space, and humidity, branched repeatedly producing the root balls inside the cavity (Fig. 9). The net of whitish rhizoliths branching over the wall of the ball would prove that after the wall's construction, new roots were incapable of penetrating it, and thus produced a net attached to the external wall, which in turn indicates that the vertical roots penetrating the chambers were the original ones, and were not cut by the producers of the chambers. This behaviour, as shown previously, is unlikely for crayfishes and vertebrates, probably because their body size compared to that of the chamber or tunnel would preclude their movements among the uncut roots.

In sum, the ball's absence at the top of the soil, the comparatively small access tunnel, the regular biconvex shape of the balls, and most of all, the pattern of root development in the balls, which is very different from that expectable inside a crayfish or vertebrate dwelling burrow, argue against crayfish feeding chambers as the origin of the Cretaceous rhizolith balls.

\subsection{The termite hypothesis. Sphaerotermes like calies}

If a large body size is an obstacle to inhabit a chamber crossed by a mass of roots, then, small sized social insects, usually constructors of large underground chambers, qualify as potential producers of these 

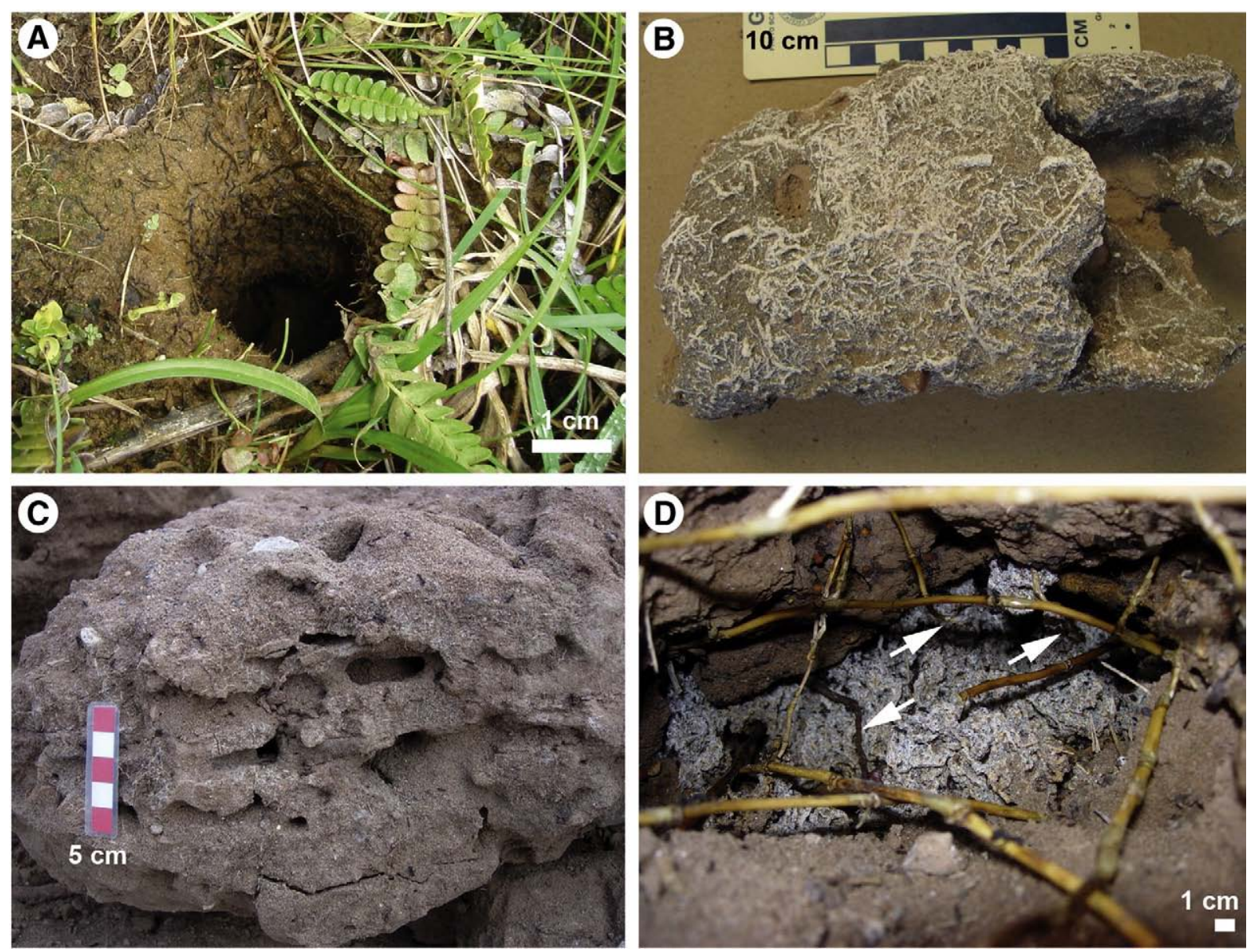

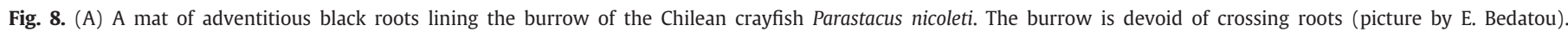

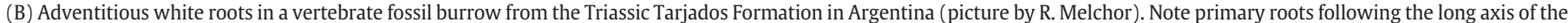

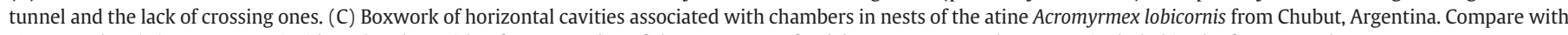
Fig. 3B and D. (D) Uncut roots inside a chamber with a fungus garden of the same nest of $A$. lobicornis. Arrows show roots included in the fungus garden.

structures. Sphaerotermes sphaerothorax is a rare taxon of African termites whose morphology and ethology allowed Engel and Krishna (2004) to separate it in a single subfamily of Termitinae. For many years it was believed that it was a fungus growing termite related to the Macrotermitinae (Grassé and Noirot, 1948), until more re-

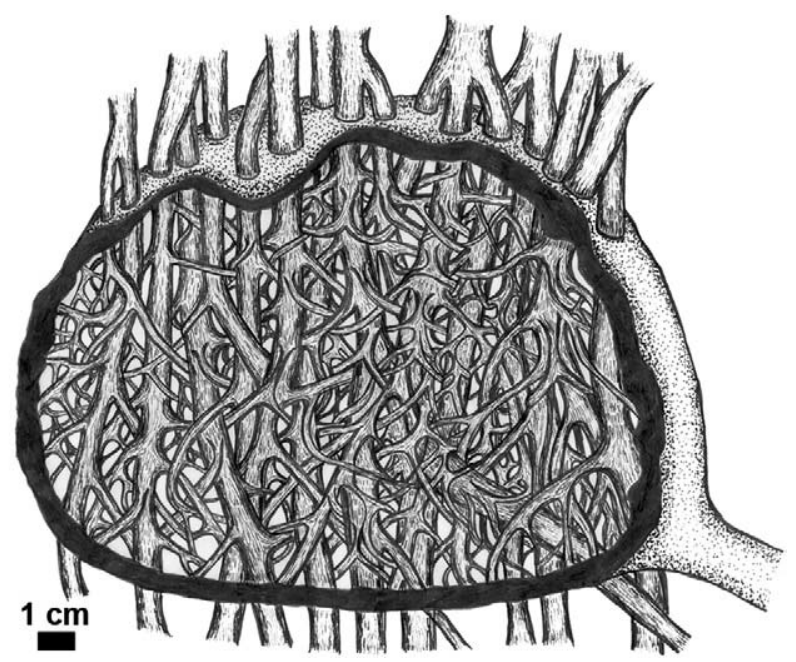

Fig. 9. Idealized reconstruction of a rhizolith ball showing the branching roots inside the cavity surrounded by a discrete wall. A tunnel arises laterally near the base. cently it was discovered that it is a xylophagous one, which uses bacteria associated to roots to digest its food (Pochon et al., 1959; Eschenbrenner, 1986; Garnier-Sillam et al., 1989). The nest of this termite has many characters comparable with the balls studied.

Sphaerotermes sphaerothorax removes the soil surrounding roots to produce a chamber in which they can grow differentially (Grassé and Noirot, 1948; Garnier-Sillam et al., 1989) probably favoured by the empty space, high humidity, and $\mathrm{O} 2$ availability as described previously for other soil organisms (Martin and Bennett, 1977; Richardson, 1983). Along with roots, associated bacteria also develop producing "bacterial combs" that termites use for digesting the wood brought to the nest in the gut or digestive system. The mouth or faecal pellets composed of recently ingested wood are deposited in the upper part of the chamber, near the combs whose bacteria attack and partly degrade them. These light pellets, which can be digested by termites, are then eaten again to finally be excreted as non-recyclable, dark pellets at the bottom of the chamber. A particular character of this nest is the presence of a constructed wall that surrounds the cavity, which is crossed by a tunnel system. This "false wall”, as so-called by Grassé and Noirot (1948), is the part of the nest really inhabited by termites, which leave the central chamber only for fungus development (Grassé and Noirot, 1948; Garnier-Sillam et al., 1989).

The shape and size of the Sphaerotermes sphaerothorax nest, its entrance tunnel, the development of root mats inside the cavity from pre-existing roots, which are not cut when excavating the chamber, and the presence of an external wall are characters that relate the Cretaceous rhizolith balls to the nest of S. sphaerothorax. However, the 
bacterial combs in that termite nest are discrete structures that may reach up to $5 \mathrm{~cm}$ of diameter (Grassé and Noirot, 1948), which are completely absent in the balls. In addition, even though the ball walls show in some cases a pelletal texture, they are not similar in structure to that of the nest. The presence of a royal cell, interconnecting galleries with constructed and complex walls, and chambers (calies) connected with other chambers are characters not recorded in the balls either.

Fungus growing termites and Sphaerotermes are exclusive of Africa. However, the final separation of South America and Africa would have occurred some time from 120 to $84 \mathrm{Ma}$, with an extrapolated age of $95 \pm 5$ Ma during the Cenomanian (Somoza and Zaffarana, 2008). In addition, for the lower Cretaceous, only representatives of the lower termites were recorded, whereas the Termitinae, including the fungus growing termites (Macrotermitinae), and the Sphaerotermitinae are supposed to have arisen only during the Paleogene (Thorne et al., 2000; Grimaldi and Engel, 2005). Consequently, the presence of a Sphaerotermes sphaerothorax's relative in South America by the Cenomanian, regarding the evolutionary history and biogeography of the group, is at once unlikely. If the producers of the rhizolith balls were termites involved in a mutualistic relationship with fungus, they should be an extinct clade, with little chances of being related to the actual fungus growing termites or Sphaerotermes, despite the significant similarity between its nests and the Cretaceous balls.

\subsection{Fungus gardens of an Attini ancestor?}

Insect fungiculture is until now a behaviour scarcely represented in the ichnofossil record. There is a single trace fossil that by now can be attributed to Attini: Attaichnus kuenzelii, which are Miocene chambers, probably fungus gardens from the central region of Argentina (Laza, 1982). This trace fossil attests for the presence of Attini in Southern South America 5-11 million years ago, which is coincident with the estimation for the origin of leaf-cutting ants obtained from a fossil calibrated molecular phylogeny (Schultz and Brady, 2008). A termite fungus garden from the Miocene of Chad (Duringer et al., 2006, 2007), which can be an important fossil evidence to calibrate the molecular phylogeny of Macrotermitinae, was described recently in Africa. Other claims on supposed Jurassic fungus growing termite nests (Bordy et al., 2004; Hasiotis, 2004) were later dismissed (Genise et al., 2005; Bromley et al., 2007 and references therein).

The evolutionary history of the Attini, the fungus growing social insects of America, as attested by body fossils and demonstrated by molecular phylogenetics began no more than 55-60 millions ago, probably during the Paleocene-Eocene Thermal Maximum (BaroniUrbani, 1980; Agosti et al., 1997; Mayhé-Nunes and Jaffé, 1998; Nel et al., 2004; Mueller et al., 2005; Brady et al., 2006; Schultz, 2007; Mueller and Rabeling, 2008; Schultz and Brady, 2008). Hence, it would be an unlikely hypothesis to propose that the producers of these balls were Attini due to all the amount of evidence provided by these disciplines. However, agriculture in insects has evolved independently 9 times (Mueller et al., 2005) and there are still other mutualistic relationships between insects in general, ants, and termites with fungi (Batra and Batra, 1967; Rouland-Lefévre, 2000; Mueller et al., 2005). Accordingly, it is still possible to explore the hypothesis of a group of ants either related to ancestral Attini or otherwise, which could have developed some kind of fungus agriculture or mutualistic relationship during the Lower Cretaceous, by comparing some characters found in the balls with those recognised in extant attine fungus gardens. The aim of such comparison, based on literature and on some observations on Acromyrmex lobicornis (Attini) nests made by some of us, would be to find some clues about the origin of fungus agriculture in ants from the ichnological perspective, still lacking in the current analyses (Mueller et al., 2001, 2005; Sánchez-Peña, 2005; Schultz 2007; Schultz and Brady, 2008).
Despite the paucity of plant remains, with the single exception of a tracheid of a gymnosperm leave (Fig. 7C), the balls share many characters with Attini fungus gardens. The presence of fungus is attested by micromorphological and SEM studies, even when they are not arranged composing discrete gardens. The size and biconvex shape of fungus gardens that have been recorded in many cases (i.e. Wheeler, 1910; Daguerre, 1945; Bonetto, 1959; Moser, 1962; Bucher, 1974) is similar to those of the balls. The access to the chambers containing the fungus garden is by means of a single lateral tunnel connected near or at the base of the chamber (i.e. Jacoby, 1944; Daguerre, 1945; Mariconi, 1970; Jonkman, 1980), similar to the structure recorded in the balls. The meniscate tunnels recorded in the balls can be attributed to insects or earthworms that usually seek organic matter in active or abandoned Attini fungus gardens (i.e. Moser, 1962; Mariconi, 1970; Weber, 1972; Zolessi and Abenante, 1973; Zolessi and González, 1974; Jonkman, 1980; Coutinho, 1984; Rabeling et al., 2007). The boxwork that occurs in the palaeosol at the same level of the balls resembles that recorded for Acromyrmex lobicornis nests (Bonetto, 1959; Zolessi and González, 1974; Genise et al, unpubl) (Fig. 8C). The wall recorded for the balls may represent different structures. It may be comparable with the mycelial veil that covers the fungus garden of Apterostigma pilosum group (Wheeler, 1910; Chapela et al., 1994; Munkacsi et al., 2004; Villesen et al., 2004; Schultz and Brady, 2008), which is supposed to be one of the most primitive Attini (Sánchez-Peña, 2005; but see Schultz, 2007; Schultz and Brady, 2008). There is another alternative that also involves a fungus origin for this wall. Fungus gardens have a life span, which has been estimated in 3-4 months in species of Atta (Weber, 1972). Dead fungus gardens are attacked by alien fungi and invaded by invertebrates and in many cases ants use chambers with dead gardens to deposit other waste materials (i.e. Bruch, 1917; Zamith et al., 1961; Moser, 1962; Mariconi, 1970; Weber, 1972; Zolessi and Abenante, 1973; Zolessi and González, 1974; Jonkman, 1980; Coutinho, 1984; Rabeling et al., 2007). In one case it has been reported that the attack by other fungus resulted in a dead garden covered by a resistant fungal layer that consolidates the whole structure (Zamith et al., 1961). Such dead gardens with resistant outer layers, probably more preservable, are also a possibility to be considered when attempting to interpret the wall and the morphological differences among the Cretaceous rhizolith balls. The wall may also represent the $2 \mathrm{~cm}$ thick mud wall, which covers the fungus gardens of A. lobicornis as reported by Zolessi and González (1974). Finally, some species of Lasius (Formicinae), which are considered when analyzing the possible origin of fungus cultivation in Attini (Mueller et al., 2001), construct walled chambers around tree roots and maintain a fungal growth in the nest walls (Hölldobler and Wilson, 1990).

An important character of the balls is the presence of roots that cross them from top to bottom. Attines leave roots inside chambers and even attach fungus gardens to them (i.e. Wheeler, 1910; Bruch, 1916, 1917, 1928; Bonetto, 1959; Moser, 1962; Weber, 1972; Garling, 1979; Genise et al., unpub) (Fig. 8D), composing a pattern comparable to that of the balls. Incidentally, fungus gardens attached to roots suggested Garling (1979) the hypothesis that fungus cultivation could have arisen from the exploitation of mycorrhizae associated with roots in underground nests. As recorded for Sphaerotermes sphaerothorax, Attini workers excavate chambers leaving roots intact to attach fungus gardens to them in the case of ants (Moser, 1962; Weber, 1972). This behaviour of chamber excavation around roots, which then branched profusely favoured by space and oxygen, is represented in the Cretaceous balls. The development of roots, as a consequence, would favour the development of any fungus related to them, and of organisms feeding on them. The mycorrhizal hypothesis was discarded by Mueller et al. (2001) because by that time it was believed that the Attini cultivated fungus from a single monophyletic clade (Lepioteaceae), which was phylogenetically distant from those associated with roots. However, the basal Attini of the Apterostigma pilosum group cultivated a still more distant group of fungus (Pterulaceae) (Chapela et al., 1994; Munkacsi 
et al., 2004; Villesen et al., 2004; Schultz and Brady, 2008). Between these two clades several groups of mycorrhizal fungi are involved, and moreover, the sister group of that including the Pterulaceae, the Hydrophoraceae, comprises mycorrhizae (Matheny et al., 2006, 2007). This new scenario weakens the argument against the mycorrhizal hypothesis (Garling, 1979), and the evidence presented herein suggests that there could have been a group of ants that cultivate fungus associated to roots by the lower Cretaceous in South America. In accordance, the actinomycete bacteria that Attines use to perform diseasesuppressing functions in gardens are also phylogenetically related to those associated with roots (Mueller et al., 2008).

Other hypothesis for the origin of Attini cultivation of fungus involved other group of ants. Some species of Lasius (Formicinae), a subfamily that has Cretaceous representatives (Grimaldi and Agosti, 2000; Nel et al., 2004), excavate chambers around roots maintaining a fungal growth in their nest walls (Hölldobler and Wilson, 1990; Mueller et al., 2001). This hypothesis was not rejected by Mueller et al. (2001), even when these authors proposed a completely different origin for the fungus agriculture. These nests also share many characters with the Cretaceous balls, such as the shape, the wall, the roots inside, and the presence of fungi.

Accordingly, the Patagonian Cretaceous balls can represent a type of primitive fungus garden, associated with roots and/or the chamber wall, produced by a non-attine ant already present by the Lower Cretaceous. Characters analyzed previously would support this hypothesis. In contrast, the lack of either discrete fungus gardens or abundant phytoliths or other plant remains preserved inside the Cretaceous balls hampers its definite demonstration.

\section{Concluding remarks}

A new type of trace fossil constituted by carbonate balls composed of a dense mass of rhizoliths is recorded from the Lower Cretaceous of Patagonia. The best preserved balls show an external wall, whose internal layers has in some cases pelletal surface texture, a tunnel entrance, and vertical rhizoliths crossing from top to base, from which a mass of smaller ones arise. Some specimens show meniscate tubes attributed to organisms different than the constructors. Micromorphological studies reveal evidence of high fungal activity associated to the original roots.

From the different hypotheses proposed to explain the origin of the balls in floodplain soils, the less probable is that the balls were produced only by a self induced and localized overgrowth of secondary and tertiary rootlets from a group of neighbouring primary roots, since there is apparently no record of this, and also because of the constant size and shape of the balls, the presence of a tunnel, and particularly because of the type of root branching.

The crayfish hypothesis involves organisms whose trace fossils are recorded from the lower Cretaceous of Patagonia, and whose habits included the excavation of feeding chambers beneath plants to obtain root and fungi mats to feed on. However, the regular biconvex shape of the trace fossils along with the small diameter of the entrance tunnel would be unusual for crayfish chambers. More important, these organisms cut the crossing roots when excavating the chambers. The balls show rhizoliths that cross them vertically, indicating that original roots were left uncut when the chamber was excavated and from which the root mass developed. A net of rhizoliths covers the chamber wall externally proving that after its construction it was impenetrable for new roots. These rhizolith patterns almost discard crayfishes completely as constructors of the balls.

The hypotheses involving social insects, termites and ants, are more risky, considering the lack of support from the body fossil record, the biogeography of extant insects, and particularly the lack of definitive evidence of fungus or bacterial gardens in the balls. However, the balls superficially resemble the nests of the African termite Sphaerotermes sphaerothorax, particularly because of the presence of roots inside a plane-convex, thick lined chamber excavated around them. However, the absence of bacterial gardens in combination with the African distribution of this taxon argues against the possibility of a close relative of this termite being the constructor of the balls. However, one extinct relative lineage cannot be completely discarded, considering that the final separation from Africa was taking place by the age of the balls.

Finally, the ant origin of these balls is at least a plausible hypothesis considering the size, shape, wall, entrance tunnel, presence of traces of associated organisms, and particularly roots. The roots and wall relate these balls to hypothesised scenarios for the origin of fungus agriculture. One hypothesis suggests that primitive Attini developed fungus agriculture from the habit of feeding on fungi associated with roots (mycorrhizae). This hypothesis is based on the fact that many Attini hang their fungus gardens from roots, which are not removed when excavating the chamber.

The balls would provide physical evidence that by the lower Cretaceous some social insects excavated chambers around roots without removing them, which in turn provided optimal conditions for fungal development. The evolutionary history of Attini and of ants in general, demonstrates that there were no possible Attini by the lower Cretaceous. However, other hypothesis for the origin of fungus agriculture, which considered that adventitious fungi on nest walls were the responsible for the arise of fungiculture, also involve chambers excavated among roots by a non-attine group of ants whose subfamily is recorded by the Cretaceous. Despite the fact that further studies will probably bring more accuracy in the attribution of these balls, their record constitutes a possible physical evidence of the origin of fungiculture in social insects, and a critical contribution of ichnology to this hot topic intensively discussed on the basis of a scattered body fossil record and molecular phylogeny.

\section{Acknowledgements}

Authors would like to thank Pablo Puerta, who discovered the trace fossils, and also to Ricardo Melchor, Jose Luis Carballido, Diego Pol, Alejandro Pardo, Georgina del Fueyo, Flavio Roces, and Orlando Cárdenas for their assistance during field work and/or preparation of the manuscript. We also thank Daniel Poiré for XRD analyses, Nadia Garrido for English revision and Luis Buatois, Finn Surlyk, and an anonymous reviewer for improving the manuscript. This work was funded by grants PICT 13286 and 1972 from the Argentine Agencia Nacional de Promoción Científica y Tecnológica to Jorge F. Genise, from a grant of the Jurassic Foundation to Diego Pol and Gerardo Cladera, and by the Fundación Egidio Feruglio. Ana María AlonsoZarza was also supported by grant CGL2005-5584-C02-02 from the Ministerio Español de Educación y Ciencia and by CCG07-UCM/AMB2299.

\section{References}

Agosti, D., Grimaldi, D., Carpenter, J.M., 1997. Oldest known ant fossils discovered. Nature 391, 447.

Alonso-Zarza, A.M., Silva, P.G., Goy, J.L., Zazo, C., 1998. Fan-surface dynamics and biogenic calcrete development: Interactions during ultimate phases of fan evolucion in the semiarid SE Spain (Murcia). Geomorphology 24, 147-167.

Alonso-Zarza, A.M., Genise, J.F., Cabrera, M.C., Mangas, J., Martín-Pérez, A., Valdeolmillos, A., Dorado-Valiño, M., 2008. Megarhizoliths in Pleistocene aeolian deposits on Gran Canaria (Spain): ichnological and palaeoenvironmental significance. Palaeogeography, Palaeoclimatology, Palaeoecology 265, 39-61.

Barbour, E.H., 1897. Nature, structure, and phylogeny of Daemonelix. Bulletin of the Geological Society of America 8, 305-314.

Baroni-Urbani, C., 1980. First description of fossil gardening ants. Stuttgarter Beiträge zur Naturkunde 54, 1-13.

Batra, L.R., Batra, S.W.T., 1967. The fungus gardens of insects. Scientific American 217, $112-120$

Bedatou, E., Melchor, R.N., Bellosi, E.S., Genise, J.F., 2008. Crayfish burrows from Late Jurassic-Late Cretaceous continental deposits of Patagonia: Argentina. Their palaeoecological, palaeoclimatic and palaeobiogeographical significance. Palaeogeography, Palaeoclimatology, Palaeoecology 257, 169-184. 
Bidartondo, M.I., Kretzer, A.M., Pine, E.M., Bruns, T.D., 2000. High root concentration and uneven ectomycorrhizal diversity near Sarcodes sanguinea (Ericaceae): a cheater that stimulates its victims? American Journal of Botany 87, 1783-1788.

Bonetto, A.A., 1959. Las hormigas cortadoras de la Provincia de Santa Fe. Dirección General de Recursos Naturales de la Provincia de Santa Fe. 84 pp.

Bordy, E.M., Bumby, A.J., Catuneanu, O., Eriksson, P.G., 2004. Advanced early Jurassic termite (Insecta: Isoptera) nests: evidence from the Clarens Formation in the Tuli Basin, Southern Africa. Palaios 19, 68-78.

Brady, S.G., Schultz, T.R., Fisher, B.L., Ward, P.S., 2006. Evaluating alternative hypotheses for the early evolution and diversification of ants. Proceedings of the National Academy of Sciences 103, 18172-18177.

Bromley, R., Buatois, L., Genise, J.F., Labandeira, C., Mángano, G., Melchor, R., Schlirf, M. Uchman, A., 2007. Comments on the paper "Reconnaissance of Upper Jurassic Morrison Formation ichnofossils, Rocky Mountain Region, USA: paleoenvironmental, stratigraphic, and paleoclimatic significance of terrestrial and freshwater ichnocoenoses" by Stephen T. Hasiotis. Sedimentary Geology 200, 141-150.

Bruch, C., 1916. Contribución al estudio de las hormigas de la provincia de San Luis Revista del Museo de La Plata 23 (2da serie), 291-357.

Bruch, C., 1917. Costumbres y nidos de hormigas. Anales de la Sociedad Científica Argentina 83, 202-316.

Bruch, C., 1928. Estudios mirmecológicos. Anales del Museo de Historia Natural de Buenos Aires 34, 341-360.

Bucher, E.H., 1974. Observaciones ecológicas sobre los artrópodos del bosque chaqueño de Tucuman. Revista de la Facultad de Ciencias Exactas, Físicas y Naturales de Córdoba Nueva Serie Biología 1, 35-122.

Carballido, J.L., Pol, D., Apesteguía, S., Bellosi, E.S., Krause, M., 2008. New materials of Chubutisaurus insignis (Sauropoda, Titanosauriformes) and basal titanosauriform relationships. Resúmenes del III Congreso Latinoamericano de Paleontología de Vertebrados, Neuquén, Argentina, p. 46.

Chapela, I.H., Rehner, S.A., Schultz, T.R., Mueller, U.G., 1994. Evolutionary history of the symbiosis between fungus-growing ants and their fungi. Science 266, 1691-1694.

Chebli, G.A., Nakayama, C., Sciutto, J.C., Serraiotto, A.A., 1976. Estratigrafía del Grupo Chubut en la región central de la provincia homónima. Actas del Congreso Geológico Argentino 1 (6), 375-392.

Codignotto, J., Nullo, F., Panza, J., Proserpio, C., 1978. Estratigrafía del Grupo Chubut entre Paso de Indios y Las Plumas, provincia del Chubut, Argentina. Actas del Congreso Geológico Argentino 1 (7), 471-480.

Coutinho, L.M., 1984. Aspectos ecológicos da saúva no cerrado - a saúva, as queimadas e sua possível relaçao na ciclagem de nutrientes minerais. Boletim de Zoologia de la Universidad de Sao Paulo 8, 1-9.

Cramer, M.D., Hawkins, H.J., 1984. A physiological mechanism for the formation of root casts. Palaeogeography, Palaeoclimatology, Palaeoecology 274, 125-133.

Currie, C.R., Scott, J.A., Summerbell, R.C., Malloch, D., 1999. Fungus-growing ants use antibiotic-producing bacteria to control garden parasites. Nature 398, 701-704.

Currie, C.M., Wong, B., Stuart, A.E., Schultz, T.R., Rehner, S.A., Mueller, U.G., Sung, G., Spatafora, J.W., Straus, N.A., 2003. Ancient tripartite coevolution in the attine antmicrobe symbiosis. Science 299, 386-388.

Daguerre, J.B., 1945. Hormigas del género Atta Frabicius de la Argentina. Revista de la Sociedad Entomológica Argentina 12, 438-460.

de la Providencia, I., de Souza, F.A., Fernandez, F., Delmas, N.S., Declerck, S., 2005. Arbuscular micorrhizal fungi reveal distinct patterns of anostomosis formation and hyphal healing mechanisms between different phylogenetic groups. New Phytologist 165, 261-271.

Dell, B., Malajczuk, N., Thomson, G.T., 1990. Ectomycorrhiza formation in Eucalyptus V. A tuberculate ectomycorrhiza of Eucalyptus pilularius. New Phytologist 114, 633-640.

Dubiel, R.F., Blodgett, R.H., Bown, T.M., 1987. Lungfish burrows in the Upper Triassic Chinle and Dolores Formation, Colorado Plateau. Journal of Sedimentary Petrology 57, 512-521.

Duringer, P., Schuster, M., Genise, J.F., Likius, A., Mackaye, H., Vignaud, P., Brunet, M., 2006. The first fossil fungus gardens of Isoptera: oldest evidence of symbiotic termite fungiculture (Miocene, Chad Basin). Naturwissenschaften 93, 610-615.

Duringer, P., Schuster, M., Genise, J.F., Mackaye, H., Vignaud, P., Brunet, M., 2007. New termite trace fossils: galleries, nests and fungus combs from the Chad Basin of Africa (Upper Miocene-Lower Pliocene). Palaeogeography, Palaeoclimatology, Palaeoecology 251, 323-353.

Engel, M.S., Krishna, K., 2004. Family-group names for termites. American Museum Novitates 3432, 1-9.

Eschenbrenner, V., 1986. Contribution des Termites á la micro-agrégation des solstropicaux. Cahier Orstom, Série Pédologie 22, 397-408.

Garling, L., 1979. Origin of ant-fungus mutualism: a new hypothesis. Biotropica 11, 284-291.

Garnier-Sillam, E., Toutain, F., Villemin, G., Renoux, J., 1989. Etudes preliminaries des meules originales du termite xylophage Sphaerotermes sphaerothorax (Sjostedt). Insectes Sociaux 36, 293-312.

Genise, J.F., 2006. Inadvertent advances on ichnotaxonomy of non-animal trace fossils: a contribution to the status quo. Abstract Book of the III Workshop on Ichnotaxonomy. Czech Geological Institute, Prague, pp. 10-11.

Genise, J.F., Bellosi, E.S., Melchor, R.N., Cosarinsky, M.I., 2005. Comment-Advanced Early Jurassic termite (Insecta:Isoptera) nests: evidence from the Clarens Formation in the Tuli Basin, Southern Africa (Bordy et al., 2004). Palaios 20, 303-305.

Genise, J.F., Bedatou, E., Melchor, R.N., 2008. Terrestrial crustacean breeding trace fossils from the Cretaceous of Patagonia (Argentina): palaeobiological and evolutionary significance. Palaeogeography, Palaeoclimatology, Palaeoecology 264, 128-139.

Giovannetti, M., Sbrana, C., Avio, L., Strani, P., 2004. Patterns of below-ground plant interconnections established by means of arbuscular mycorrhizal networks. New Phytologist 164, 175-181. Mylagaulidae) from the late Miocene (Barstovian) Pawnee Creek Formation of northeastern Colorado. Palaeogeography, Palaeoclimatology, Palaeoecology 237, 119-136.

Grassé, P., Noirot, C., 1948. Sur le nid et la biologie du Sphaerotermes sphaerothorax (Sjöstedt). Annales des Sciences Naturelles, Zoologie 11 Série 10, 149-165.

Grimaldi, D.A., Agosti, D., 2000. A formicinae in New Jersey Cretaceous amber (Hymenoptera: Formicidae) and early evolution of the ants. Proceedings of the National Academy of Science 97, 13678-13683.

Grimaldi, D.A., Engel, M.S., 2005. Evolution of the Insects. Cambridge University Press, New York. 755 pp.

Growns, I.O., Richardson, A.M., 1988. Diet and burrowing habits of the freshwater crayfish, Parastacoides tasmanicus tasmanicus Clark (Decapoda: Parastacidae). Australian Journal of Marine and Freshwater Research 39, 525-534.

Hasiotis, S.T., 2004. Reconnaissance of Upper Jurassic Morrison Formation ichnofossils, Rocky Mountain Region, USA: paleoenvironmental, stratigraphic, and paleoclimatic significance of terrestrial and freshwater ichnocoenoses. Sedimentary Geology 167, 177-268.

Hasiotis, S.T., Wellner, R.W., Martin, A.J., Demko, T.M., 2004. Vertebrate burrows from Triassic and Jurassic continental deposits of North America and Antarctica: their paleoenvironmental and paleoecological significance. Ichnos 11, 103-124.

Hobbs, H.H., 1981. The crayfishes of Georgia. Smithsonian Contributions to Zoology 318, 1-536.

Hölldobler, B., Wilson, E.O., 1990. The Ants. Harvard University Press, Cambridge, Masschusetts. $732 \mathrm{pp}$.

Horwitz, P., Knott, B., 1983. The burrowing habit of the koonac Cherax plebeius (Decapoda: Parastacidae). West Australian Naturalist 15, 113-117.

Horwitz, P.H., Richardson, A.M., Boulton, A., 1985. The burrow habitat of two sympatric species of land crayfish, Engaeus urostrictus and E. tuberculatus (Decapoda: Parastacidae). Victorian Naturalist 102, 188-197.

Jacoby, M., 1944. Observacoes e experiéncias sóbre Atta sexdens rubropilosa Forel visando facilitar seu combate. Boletim do Ministerio de Agricultura do Rio de Janeiro $12,1-55$.

Jonkman, J.C., 1980. The external and internal structure and growth of nests of the leafcutting ant Atta vollenweideri Forel, 1893 (Hym: Formicidae). Part II. Zeitschrift für Angewandte Entomologie 89, 217-246.

Klappa, C.F., 1980. Rhizoliths in terrestrial carbonates: classification, recognition, genesis and significance. Sedimentology 27, 613-629.

Kraus, M.J., Hasiotis, S.T., 2006. Significance of different modes of rhizolith preservation to interpreting paleoenvironmental and paleohydrologic settings: examples from Paleogene paleosols, Bighorn Basin, Wyoming, U.S.A. Journal of Sedimentary Research 76, 633-646.

Lake, P.S., Newcombe, K.J., 1975. Observations on the ecology of the crayfish Parastacoides tasmanicus (Decapoda: Parastacidae) from South-Western Tasmania. Australian Zoology 18, 197-214.

Lamont, B.B., 2003. Structure, ecology, physiology and root clusters - a review. Plant and Soil 248, 1-19.

Laza, J.H., 1982. Signos de actividad atribuibles a Atta (Myrmicidae) en el Mioceno de la Provincia de La Pampa, República Argentina. Significación paleozoogeográfica. Ameghiniana 19, 109-124.

Lesta, P.J., 1968. Estratigrafía de la Cuenca del Golfo de San Jorge. Actas de las Terceras Jornadas Geológicas Argentinas 1, 251-289.

Loisy, C., Verrecchia, E.P., Dufour, P., 1999. Microbial origin for pedogenid micrite associated with a carbonate paleosol (Champagne, France). Sedimentary Geology 126, 193-204.

Mariconi, F.A., 1970. As Saúvas. Editora Agronómica Ceres, San Pablo. 155 pp.

Martin, L.D., Bennett, D.K., 1977. The burrows of the Miocene beaver Palaeocastor, Western Nebraska, U.S.A. Palaeogeography, Palaeoclimatology, Palaeoecology 221, 173-193.

Matheny, P.B., Curtis, J.M., Hofstetter, V., Aime, M.C., Moncalvo, J.M., Ge, Z.W., Yang, Z.L., Slot, J.C., Ammirati, J.F., Baroni, T.J., Bougher, N.L., Hughes, K.W., Lodge, D.J., Kerrigan, R.W., Seidl, M.T., Aanen, D.K., DeNitis, M., Daniele, G.M., Desjardin, D.E., Kropp, B.R., Norvel, L.L., Parker, A., Vellinga, E.C., Vilgalys, R., Hibbett, D.S., 2006. Major clades of Agaricales: a multilocus phylogenetic overview. Mycologia 98, 982-995.

Matheny, B., Moncalvo, J.M., Redhead, S.A., 2007. Agaricales. Version 09 May 2007. http://tolweb.org/Agaricales/20551/2007.05.09 in The Tree of Life Web Project, http://tolweb.org/.

Mayhé-Nunes, A.J., Jaffé, K., 1998. On the biogeography of Attini (Hymenoptera: Formicidae). Ecotropicos 11, 45-54

Mikuláš, R., 1999. Notes on the concept of plant trace fossils related to plant-generated sedimentary structures. Vestník Cěského Geologického Ústavu 74, 39-42.

Moser, J.C., 1962. Contents and structure of Atta texana nest in summer. Annals of the Entomological Society of America 56, 286-291.

Mueller, U.G., Rabeling, C., 2008. A breakthrough innovation in animal evolution. Proceedings of the National Academy of Sciences 105, 5287-5288.

Mueller, U.G., Rehner, S.A., Schultz, T.R., 1998. The evolution of agriculture in ants. Science 281, 2034-2038.

Mueller, U.G., Schultz, T.R., Currie, C.R., Adams, R.M., Malloch, D., 2001. The origin of the attine ant-fungus mutualism. Quarterly Review of Biology 76, 169-197.

Mueller, U.G., Gerardo, N.M., Aanen, D.K., Six, D.L., Schultz, T.R., 2005. The evolution of agriculture in insects. Annual Review of Ecology and Evolutionary Systematic 36, 563-595.

Mueller, U.G., Dash, D., Rabeling, C., Rodrigues, A., 2008. Coevolution between attine ants and actinomycete bacteria: a reevaluation. Evolution. 62, 2894-2912

Munkacsi, A.B., Pan, J.J., Villesen, P., Mueller, U.G., Blackwell, M., McLaughlin, D.J., 2004 Convergent coevolution in the domestication of coral mushrooms by fungusgrowing ants. Proceedings of the Royal Society of London B 271, 1777-1782. 
Musacchio, E.A., 1972. Carófitas del Cretácico inferior en sedimentitas "chubutenses" al este de La Herrería, Chubut. Ameghiniana 9, 354-356.

Musacchio, E.A., Chebli, G., 1975. Ostrácodos no marinos y carófitas del Cretácido inferior en las provincias de Chubut y Neuquén, Argentina. Ameghiniana 12, 70-95.

Nel, A. Perrault, G., Perrichot, V., Néraudeau, D. 2004. The oldest ant in the Lowe Cretaceous amber of Charente-Maritime (SW France) (Insecta: Hymenoptera: Formicidae). Geologica Acta 2, 23-29.

Newmann, G., Martinoia, E., 2002. Cluster roots - an underground adaptation for survival in extreme environments. Trends in Plant Science 7, 162-167.

Peterson, R.L., Massicotte, H.B., Melville, L.H., 2004. Mycorrhizas: Anatomy and Cell Biology. NRC Research Press, Otawa. 173 pp.

Pochon, J., De Barjac, H., Roche, A., 1959. Recherches sur la digestion de la cellulose chez le termite Sphaerotermes sphaerothorax. Annales de l'Institut Pasteur 96, 352-355.

Proserpio, C.A., 1987. Descripción geológica de la Hoja 44e, Valle General Racedo, provincia del Chubut. Boletín de la Dirección Nacional de Minería y Geología 201, $1-92$.

Rabeling, C., Verhaagh, M., Engels, W., 2007. Comparative study of nest architecture and colony structure of the fungus-growing ants, Mycocepurus goeldii and M. smithii. Journal of Insect Science 7 article 40. (www.insectscience.org).

Richardson, A.M., 1983. The effect of the burrows of a crayfish on the respiration of the surrounding soil. Soil Biology and Biochemistry 15, 239-242.

Richardson, A.M., Wong, V., 1995. The effect of a burrowing crayfish, Parastacoides sp. on the vegetation of Tasmanian wet Heathlands. Freshwater Crayfish 10, 174-182.

Rouland-Lefévre, C., 2000. Symbiosis with fungi. In: Abe, T., Bignell, D.E., Higashi, M (Eds.), Termites: Evolution, Sociality, Symbioses, Ecology. Kluwer Academic, Dordrecht, pp. 289-306.

Rudolph, E.H., 1997. Aspectos fisicoquímicos del habitat y morfología de las galerias de camaron excavador Parastacus nicoletti (Philippi, 1882) (Decapoda: Parastacidae) en el sur de Chile. Gayana Zoología 61, 97-108.

Sánchez-Peña, S.R., 2005. New view on origin of attine ant-fungus mutualism: exploitation of a pre-existing insect-fungus symbiosis (Hymenoptera: Formicidae). Annals of the Entomological Society of America 98, 151-164.

Schultz, T.R., 2007. The fungus-growing ant genus Apterostigma in Dominican amber. In: Snelling, R.R., Fisher, B.L., Ward, P.S. (Eds). Advances in ant systematics (Hymenoptera: Formicidae): homage to E.O. Wilson-50 years of contributions. Memoirs of the American Entomological Institute 80, 425-436.

Schultz, T.R., Brady, S.G., 2008. Major evolutionary transitions in ant agriculture. Proceedings of the National Academy of Sciences 105, 5435-5440.

Shane, M.W., Lambers, H., 2005. Cluster roots: a curiosity in context. Pland and Soil 274 $101-125$.
Skene, K.N., 1998. Cluster roots: some ecological considerations. Journal of Ecology 86 , 1060-1064.

Smith, R., 1987. Helical burrow casts of therapsid origin from the Beaufort Group (Permian) of South Africa. Palaeogeography, Palaeoclimatology, Palaeoecology 60 $155-170$.

Somoza, R., Zaffarana, C., 2008. Mid-Cretaceous polar standstill of South America, motion of the Atlantic hotspots and the birth of the Andean cordillera. Earth and Planetary Science Letters 271, 267-277.

Suter, P.J., Richardson, A.M., 1977. The biology of two species of Engaeus (Decapoda: Parastacidae) in Tasmania III. Habitat, food, associated fauna and distribution. Australian Journal of Marine and Freshwater Research 28, 95-103.

Thorne, B.L., Grimaldi, D.A., Krishna, K., 2000. Early fossil history of the termites. In: Abe, T., Bignell, D.E., Higashi, M. (Eds.), Termites: Evolution, Sociality, Symbioses, Ecology. Kluwer Academic, Dordrecht, pp. 77-93.

Verrecchia, E.P., Verrecchia, K.E., 1994. Needle fiber calcite: a critical review and a proposed classification. Journal of Sedimentary Research 64, 650-664.

Villesen, P., Mueller, U.G., Schultz, T.R., Adams, R.M., Bouck, A.M., 2004. Evolution of antcultivar specialization and cultivar switching in Apterostigma fungus growing ants. Evolution 58, 2252-2265.

Weber, N.A., 1972. Gardening Ants: The Attines. The American Philosophical Society, Philadelphia. $146 \mathrm{pp}$.

Wheeler, W.M., 1910. Ants. Columbia University Press, New York. 663 pp.

Wright, V.P., 1986. The role of fungal biomineralization in the formation of Early Carboniferous soil fabrics. Sedimentology 33, 831-838.

Yelinek, K., Chin, K., 2007. Probable dung beetle burrows associated with Daemonelix (beaver burrows) in the Miocene Harrison Formation, Nebraska, U.S.A. In: Bromley, R.S., Buatois, L.A., Mángano, G., Genise, J.F., Melchor, R.N. (Eds.), SedimentOrganism Interactions: A Multifaceted Ichnology: SEPM Special Publication, vol. 88, pp. 345-352. Oklahoma.

Zamith, A.P., Mariconi, F.A., Paiva Castro, U., 1961. Contribuiçáo para o conhecimento da "saúva mata pasto" Atta bispherica Forel 1908. Anais da Escola Superior de Agricultura "Luiz de Queiroz" 18, 327-338.

Zolessi, L.C., Abenante, Y.P., 1973. Nidificación y mesoetología de Acromyrmex en el Uruguay III. Acromyrmex (A.) hispidus Santschi, 1925 (Hymenoptera, Formicidae). Revista de Biología del Uruguay 1, 151-165.

Zolessi, L.C., González, L.A., 1974. Nidificación y mesoetología de Acromyrmex en el Uruguay II. Acromyrmex (Acromyrmex) lobicornis (Emery, 1887) (Hymenoptera, Formicidae). Revista de Biología del Uruguay 1, 37-57. 